\title{
Ablation of Kappa-Opioid Receptors from Brain Dopamine Neurons has Anxiolytic-Like Effects and Enhances Cocaine-Induced Plasticity
}

\author{
Ashlee Van't Veer ${ }^{1,4}$, Anita J Bechtholt ${ }^{1,4}$, Sara Onvani', David Potter', Yujun Wang' ${ }^{2}$, Lee-Yuan Liu-Chen ${ }^{2}$, \\ Günther Schütz ${ }^{3}$, Elena H Chartoff', Uwe Rudolph', Bruce M Cohen' and William A Carlezon Jr*,' \\ 'Department of Psychiatry, Harvard Medical School, McLean Hospital, Belmont, MA, USA; ${ }^{2}$ Department of Pharmacology, Temple University \\ School of Medicine, Philadelphia, PA, USA; ${ }^{3}$ Division of Molecular Biology of the Cell I, German Cancer Research Center, Heidelberg, Germany
}

\begin{abstract}
Brain kappa-opioid receptors (KORs) are implicated in states of motivation and emotion. Activation of KORs negatively regulates mesolimbic dopamine (DA) neurons, and KOR agonists produce depressive-like behavioral effects. To further evaluate how KOR function affects behavior, we developed mutant mice in which exon 3 of the KOR gene (Oprk I) was flanked with Cre-lox recombination (loxP) sites. By breeding these mice with lines that express Cre-recombinase (Cre) in early embryogenesis (Ella-Cre) or only in DA neurons (dopamine transporter (DAT)-Cre), we developed constitutive KOR knockouts (KOR ${ }^{-1-}$ ) and conditional knockouts that lack KORs in DA-containing neurons (DAT-KOR ${ }^{\text {lox/lox }}$ ). Autoradiography demonstrated complete ablation of KOR binding in the $\mathrm{KOR}^{-1-}$ mutants, and reduced binding in the DAT-KOR ${ }^{\text {lox/lox }}$ mutants. Quantitative reverse transcription PCR (qPCR) studies confirmed that KOR mRNA is undetectable in the constitutive mutants and reduced in the midbrain DA systems of the conditional mutants. Behavioral characterization demonstrated that these mutant lines do not differ from controls in metrics, including hearing, vision, weight, and locomotor activity. Whereas $\mathrm{KOR}^{-1-}$ mice appeared normal in the open field and light/dark box tests, DAT-KOR ${ }^{\text {lox/lox }}$ mice showed reduced anxiety-like behavior, an effect that is broadly consistent with previously reported effects of KOR antagonists. Sensitization to the locomotor-stimulating effects of cocaine appeared normal in $\mathrm{KOR}^{-1-}$ mutants, but was exaggerated in DAT$\mathrm{KOR}^{\text {lox/lox }}$ mutants. Increased sensitivity to cocaine in the DAT-KOR ${ }^{\text {lox/lox }}$ mutants is consistent with a role for KORs in negative regulation of DA function, whereas the lack of differences in the $\mathrm{KOR}^{-1}$ - mutants suggests compensatory adaptations after constitutive receptor ablation. These mouse lines may be useful in future studies of KOR function.

Neuropsychopharmacology (2013) 38, I585-1597; do: I0.1038/npp.2013.58; published online 20 March 20I3
\end{abstract}

Keywords: kappa-opioid receptor; mutation; dopamine; anxiety; cocaine.

\section{INTRODUCTION}

Accumulating evidence indicates that brain kappa-opioid receptors (KORs) and dynorphin (DYN), the endogenous ligand that binds at these receptors (Chavkin et al, 1982), are involved in regulating states of motivation and emotion. Administration of KOR agonists produces depressive (dysphoric) effects in humans (Pfeiffer et al, 1986) and depressive-like effects in rodents (for review, see Carlezon et al, 2009; Bruchas et al, 2010; Knoll and Carlezon, 2010). In contrast, KOR antagonists produce antidepressant-like effects (for review, see Carlezon et al, 2009; Carlezon and Carroll, 2013). Although the mechanisms through which

*Correspondence: Dr WA Carlezon Jr, Department of Psychiatry, McLean Hospital, MRC 217, I 5 Mill Street, Belmont, MA 02478, USA, Tel: +617855 2021, Fax: +6178552023,

E-mail: bcarlezon@mclean.harvard.edu

${ }^{4}$ These authors contributed equally to this work.

Received 18 January 2013; Revised 20 February 2013; Accepted 21

February 2013; accepted article preview online 27 February 2013
KORs regulate mood are not fully understood, actions upon the mesocorticolimbic dopamine (DA) system appear to have a key role. KORs are expressed on both the cell bodies and terminals of mesocorticolimbic (ventral tegmental area (VTA)) DA neurons (Svingos et al, 1999; Svingos et al, 2001) and are coupled to G-proteins, such that agonist stimulation inhibits cyclic AMP production and modulates potassium and calcium channel conductance (Bruchas and Chavkin, 2010). These processes produce inhibition of DA neurons in the VTA (Margolis et al, 2003; Margolis et al, 2006; Ford et al, 2007) and diminished DA release in areas that receive VTA input such as the nucleus accumbens (NAc) and prefrontal cortex (PFC), regardless of whether the agonist is given systemically (Di Chiara and Imperato, 1988; Devine et al, 1993; Carlezon et al, 2006), into the VTA (Margolis et al, 2006) or into the NAc (Donzanti et al, 1992). Systemic administration of KOR agonists also attenuates cocaine effects on behavior (Tomasiewicz et al, 2008) and DA neurochemistry (Maisonneuve et al, 1994; Thompson et al, 2000). KOR antagonists cause small elevations in extracellular concentrations of DA in the NAc 
(Maisonneuve et al, 1994), consistent with a neuromodulatory role of KORs and DYN. Collectively, these studies suggest that manipulations that target KORs may be useful in the study and treatment of debilitating conditions characterized by dysregulation of motivation and emotion, such as mood disorders and addiction.

There is increasing interest in the development of KORtargeted ligands as therapeutic agents. It has been suggested that KOR antagonists might have a wide range of indications, including the treatment of depressive-, anxiety-, and addictive disorders (for review, see Carlezon et al, 2009; Wee and Koob, 2010; Tejeda et al, 2012; Carlezon and Carroll, 2013). A general ability to reduce the impact of stress may explain how KOR antagonists can have efficacy in such a wide variety of animal models that would appear to represent different disease states (Bruchas et al, 2010; Knoll and Carlezon, 2010; Van't Veer et al, 2012; Carlezon and Carroll, 2013). Partial KOR agonists, which activate KORs with a lower efficacy than DYN and thus may lack the dysphoric effects produced by full agonists, could be useful for the treatment of conditions characterized by elevated motivation (Carlezon et al, 2009). One such condition is mania (Cohen and Murphy, 2008), a hallmark sign of bipolar disorder. Full KOR agonists have long been of interest as non-addictive analgesic drugs (Pasternak, 1980) or anti-itch medications (Inan and Cowan, 2004). Although current full KOR agonists produce dysphoric effects that may render them difficult for patients to tolerate, recent work suggests that it may be possible to identify new generations of these agents that have the desired effects on pain without aversive side effects (Bruchas et al, 2011). As such, a broader understanding of the neurobiology of KOR function may facilitate the development of new and improved medications.

One strategy to understand the neurobiological significance of KORs is to develop mutant mice that lack these receptors. We generated a line of mice in which exon 3 of the KOR gene (opioid receptor, kappa 1 (Oprk1)) was targeted for deletion by flanking it with Cre-lox (loxP) recombination sites, thereby enabling conditional (region-specific) KOR deletion and allowing the design of new studies that complement work conducted in previously reported lines (Chefer et al, 2005). By breeding these mice with lines that express Cre-recombinase (Cre) in early embryogenesis (EIIa-Cre) or only in DA neurons (dopamine transporter (DAT)-Cre), we developed constitutive KOR knockouts $\left(\mathrm{KOR}^{-1-}\right)$ and conditional knockouts that lack KORs in DA-containing neurons (DAT$\left.\mathrm{KOR}^{\text {lox/lox }}\right)$. Here we describe initial characterization of these mice in molecular assays to confirm the efficacy of the mutation, as well as in a battery of behavioral tests that quantify effects of the mutations on metrics including hearing, vision, weight, locomotor activity in an open field and anxiety. We also examined the effects of acute and repeated cocaine on behavior in these mice, for comparison with findings from previous reports (Chefer et al, 2005). This early work provides a basis for future studies of KOR function in these mice.

\section{MATERIALS AND METHODS}

\section{Mice}

Mice were group-housed ( $2-5$ mice/cage) and maintained on a $12: 12$-h light-dark cycle ( 0700 hours lights on) with ad libitum food and water available except during behavioral testing. Experiments were conducted in male mice 2 to 4 months at the start of each experiment and testing occurred during the light phase of the daily cycle. Mice tested in the light/dark box test were also tested 7 days later in the elevated plus maze (EPM). For all of the other individual experiments, naive (previously untested) mice were used. Some additional tests were performed on the DAT-KOR ${ }^{\text {lox/lox }}$ mice and appropriate controls to follow-up positive findings in initial screening procedures (see below). Experimental protocols were approved by the Institutional Animal Care and Use Committee of McLean Hospital and in accordance with the National Institutes of Health policies.

\section{Development of Mutant Mice}

The murine KOR gene (Oprk1) contains 4 exons. A targeting construct was generated in which loxP sites flanked exon 3 of this gene (inGenious Targeting Laboratory (iTL), Ronkonkoma, NY). Protein lacking this region would be non-functional as the excision shifts the open reading frame, which ensures that subsequent portions of the protein are not translated. For positive selection of homologous recombinants, an FRT-flanked neomycin resistance gene (neo) was cloned downstream of exon 3 (Figure 1). The targeting vector was linearized and transfected by electroporation into iTL IC1 C57BL/6NTac embryonic stem (ES) cells. Recombinant ES clones were microinjected into BALB/c blastocytes and resulting chimeras were mated with wild-type (WT) C57BL/6 mice to generate F1 heterozygotes. Correct targeting was confirmed by PCR with primers hybridizing to the neo gene ( $5^{\prime}$-GTACTGTATCAGTAGACATTGG-3') and a flanking primer $3^{\prime}$ to the short homology arm $\left(5^{\prime}\right.$-CCAGAGGCCA CTTGTGTAGC- $\left.3^{\prime}\right)$. The neomycin cassette was then removed by breeding heterozygous offspring to ACTFLPe mice (Jackson Labs, Bar Harbor, ME). Mice that no longer contained the FLPe transgene but retained the loxP sites were intercrossed to generate homozygote Oprk1-floxed mice $\left(\mathrm{KOR}^{\text {lox/lox }}\right)$. We then crossed $\mathrm{KOR}^{\mathrm{lox} / \mathrm{lox}}$ with mice expressing Cre during early embryonic development (EIIaCre; Jackson Labs, Bar Harbor, ME), thereby generating

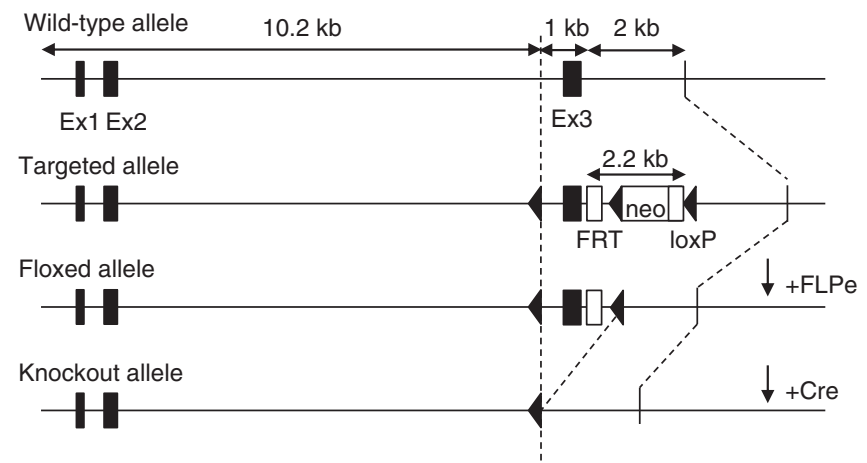

Figure I Generation of KOR-deficient mice. Representative depiction of the wild-type, targeted, floxed, and knockout alleles. The neo cassette was removed from the targeted allele by FLPe-induced recombination. Mutant mice were generated by breeding to Ella- and DAT-Cre mouse lines to generate constitutive knockouts and conditional knockouts in which KORs ablated in DA neurons, respectively. 
constitutive KOR knockouts $\left(\mathrm{KOR}^{-1-}\right)$, and with mice expressing Cre in DAT-containing cells (DAT-Cre line 9075; Parlato et al, 2006). Previous work has demonstrated that Cre expression is restricted to DA neurons in line 9075 (Parlato et al, 2006), and thus crossing these mice with our $\mathrm{KOR}^{\text {lox/lox }}$ mouse generated conditional knockouts that lack KORs specifically in DA-containing neurons $\left(\mathrm{DAT}-\mathrm{KOR}^{\text {lox/lox}}\right)$. Mice were backcrossed to C57BL/6J (seven generations) before testing. For experiments, $\mathrm{KOR}^{-1-}$ mice and littermate controls $\left(\mathrm{KOR}^{+1+}\right)$ were obtained by breeding KOR heterozygous $\left(\mathrm{KOR}^{+/-}\right)$mice. DAT- KOR ${ }^{\text {lox/lox }}$ and littermate controls $\left(\mathrm{KOR}^{\mathrm{lox} / \mathrm{lox}}\right)$ were obtained by breeding floxed KOR mice expressing the DATCre transgene with floxed mice lacking the Cre transgene.

\section{Genotyping}

Genomic DNA samples obtained from tail biopsies were tested by PCR to demonstrate recombination at the floxed KOR allele using primers annealing immediately upstream of each loxP site and just downstream of the floxed region (5'-TATTGCTGACCTATCGTGAAC- $3^{\prime}$, 5'-GAGCTACTGTTTTCATACCATTTA-3', and 5'-TTGAGG CTACTAGTTTCCAAAG-3'). PCR products were run on a $1 \%$ agarose gel. Expected fragment sizes were $399 \mathrm{bp}$ for WT DNA, $459 \mathrm{bp}$ for unrecombined DNA, and $563 \mathrm{bp}$ for the knockout. PCR cycling conditions were $94^{\circ} \mathrm{C}, 45 \mathrm{~s} ; 60^{\circ} \mathrm{C}$, $20 \mathrm{~s} ; 70^{\circ} \mathrm{C}, 1 \mathrm{~min}$ for 40 cycles. To determine whether mice expressed the Cre transgene, genotyping was performed with primers to iCre (5'-GTGGATGCCACCTCTGATG AAGTCAGGA- $3^{\prime}$ and $5^{\prime}$-CAATGCGCAGCAGGGTGTTGTA GGCAAT- $3^{\prime}$ ).

\section{Autoradiography}

Autoradiography was performed using $\left[{ }^{3} \mathrm{H}\right] \mathrm{U} 69,593$ (PerkinElmer, Waltham, MA), a tritiated version of a highly selective KOR agonist (La Regina et al, 1988), as described previously (Wang et al, 2011). Mice were killed by decapitation, and brains were removed and immediately immersed in isopentane on dry ice. Coronal sections $(20 \mu \mathrm{m})$ were cut on a cryostat (CM3050 S, Leica, Wetzlar, Germany) maintained at $-20^{\circ} \mathrm{C}$, thaw-mounted onto gelatin-dipped slides, and stored at $-80^{\circ} \mathrm{C}$ until processed. Sections were incubated with $5 \mathrm{~nm}\left[{ }^{3} \mathrm{H}\right] \mathrm{U} 69,593$ in $50 \mathrm{~mm}$ Tris- $\mathrm{HCl}$ buffer $(\mathrm{pH} 7.4)$ for $1 \mathrm{~h}$ at $25^{\circ} \mathrm{C}$. Non-specific binding was assessed in the presence of $10 \mu \mathrm{m}$ naloxone, a non-specific opiate receptor inhibitor. Slides were then rinsed three times ( $2 \mathrm{~min}$ each) in cold $50 \mathrm{~mm}$ Tris- $\mathrm{HCl}$ buffer, $\mathrm{pH}$ 7.4, and once $(30 \mathrm{~s})$ in deionized $\mathrm{H}_{2} \mathrm{O}$, dried under a cool stream of air, and exposed to tritium-sensitive storage phosphor screens for 3 weeks in cassettes. Radioactive images captured on phosphor screens along with $\left[{ }^{3} \mathrm{H}\right]$ microscale standards (GE Healthcare, Buckinghamshire, UK) were visualized using a Cyclone Storage Phosphor Scanner (Packard Bioscience, Meriden, CT), and data were analyzed using the OptiQuant program. Nonspecific binding was subtracted from total binding from serially adjacent sections and the resultant values represent specific $\left[{ }^{3} \mathrm{H}\right] \mathrm{U} 69,593$ binding in $\mathrm{fmol} / \mathrm{mg}$ as determined using $\left[{ }^{3} \mathrm{H}\right]$ microscale. Data are reported as mean values plus SEM from three to four sections in each brain.

\section{qPCR}

To complement the autoradiography studies, we performed qPCR on cDNA synthesized from tissue punches of the NAc, caudate putamen ( $\mathrm{CPu}$ ), amygdala (AMY), and midbrain (comprising the VTA plus substantia nigra (VTA/SN). Frozen brains were coronally sectioned on a cryostat $\left(-20^{\circ} \mathrm{C}\right)$ until the rostral NAc was exposed (Bregma $1.70 \mathrm{~mm}$ ). Bilateral $1-\mathrm{mm}^{3}$ punches of NAc tissue were taken and kept on dry ice. More caudal brain regions of interest were sequentially obtained by sectioning until the rostral face of the region was exposed and bilateral tissue punches obtained (average tissue weight $\approx 15.0 \mathrm{mg}$ ). To verify the location of the tissue punches, $30-\mu \mathrm{m}$ coronal sections were collected at the beginning and end of each punch; these sections were slide mounted, stained with $0.1 \%$ cresyl violet, and analyzed to verify that the tissue punch location was within the targeted brain regions. Total RNA was extracted using PureLink RNA Mini Kit (Life Technologies, Carlsbad, CA). RNA quality and quantity were assessed using an RNA 6000 Nano Chip (Agilent, Santa Clara, CA) on an Agilent Bioanalyzer 2100. RNA integrity number exceeded seven for all samples, indicating high quality. Five hundred nanograms of total RNA was used to synthesize cDNA for each sample using iScript cDNA Synthesis Kit (BioRad, Hercules, CA) in a ThermoHybaid iCycler (Thermo Scientific, Waltham, MA). Primers specific for KOR (Oprk1; 5'-TCCTTGGAGGCACCAAAGTCAG GG-3', and $5^{\prime}$-TGGTGATGCGGCGGAGATTTCG- $3^{\prime}$ ), DAT (Slc6a3; $5^{\prime}$-AATGCCCTGGGCTGGATCATTGC- $3^{\prime}$ and $5^{\prime}$-AATGGCG CAGCGTGAATTGGC- $\left.3^{\prime}\right), \quad \beta$-actin ( $\mathrm{Nba} ; 5^{\prime}$-AGTGTGACG TTGACATCCGTA- $3^{\prime}$ and $5^{\prime}$-GCCAGAGCAGTAATCTC CTTCT- $3^{\prime}$ ), and filamin $\beta$ protein $\left(F \ln B ; 5^{\prime}-\right.$ TTCACT GTGGGCGTTGCTGC- $3^{\prime}$ and $5^{\prime}$-AAGCATGGCACCACCTTC CG-3') genes were designed using NCBI Primer-BLAST (http://www.ncbi.nlm.nih.gov/tools/primer-blast/) and purchased from Integrated DNA Technologies (Coralville, Johnson County, IA). The KOR primer set flanked the exon 3 to exon 4 junction. Melt curve analysis and polyacrylamide gel electrophoresis confirmed the specificity of the primers. The amplicon base pair lengths are 237 (KOR), 178 (DAT), 112 ( $\beta$-actin), and 176 (FlnB).

The qPCR was run using the iQ SybrGreen Supermix (BioRad). The reaction was carried out on a MyiQ Single Color Real-Time PCR Detection System (BioRad) in a volume of $20 \mu \mathrm{l}$, with $2.0 \mu \mathrm{l}$ of $3.0 \mu \mathrm{M}$ forward and reverse primers, $2.0 \mu \mathrm{l}$ Rnase/Dnase-free $\mathrm{H}_{2} \mathrm{O}, 10 \mu \mathrm{l}$ SybrGreen Supermix, and $4.0 \mu \mathrm{l} \mathrm{cDNA}$ sample diluted $1: 10$. PCR cycling conditions were $95^{\circ} \mathrm{C}$ for $5 \mathrm{~min} ; 40$ cycles at $94^{\circ} \mathrm{C}$ for $15 \mathrm{~s}, 60^{\circ} \mathrm{C}$ for $15 \mathrm{~s}, 72{ }^{\circ} \mathrm{C}$ for $15 \mathrm{~s}$. Data were collected at a read temperature of $81{ }^{\circ} \mathrm{C}$ to $83^{\circ} \mathrm{C}$ for $15 \mathrm{~s}$ depending on the amplicon melt temperatures. Standard dilution curves were generated for each primer in every experiment and on every plate by serially diluting $(1.00,0.25,0.0625$, and 0.0156 -fold $)$ a master cDNA stock comprising an equal mix of cDNA pooled from the brain regions of interest of all control mice. The undiluted master sample was assigned an arbitrary concentration of 1.00. MyiQ Optical System Software (BioRad) was used to analyze the data, and reported values for KOR and DAT were normalized to the average of two internal controls: $\beta$-actin, and FlnB, neither of which showed group differences in qPCR analyses. Samples 
containing no cDNA template and samples from cDNA reactions containing no reverse transcriptase were run as controls for contamination and amplification of genomic DNA, respectively. All samples were run in duplicate. In experiments that compared gene expression in the NAc, $\mathrm{CPu}, \mathrm{AMY}$, and VTA/SN, qPCR reactions for $\mathrm{KOR}$ and internal control gene analysis were run concurrently with all samples from these regions on the same 96-well plate, to ensure identical amplification and measurement conditions.

\section{Cre Immunohistochemistry}

Mice were perfused with $0.9 \%$ saline followed by $4 \%$ paraformaldehyde. Whole brains were extracted and postfixed in $4 \%$ paraformaldehyde overnight and then transferred to $30 \%$ sucrose for cryoprotection. Brains were sectioned at $30 \mu \mathrm{m}$ and incubated in $0.3 \% \mathrm{H}_{2} \mathrm{O}_{2}$ for $30 \mathrm{~min}$, then blocked in 5\% normal goat serum (Vector Laboratories, Burlingame, CA), for $1 \mathrm{~h}$. Sections were incubated in a primary antibody to Cre ( $1: 2000$; Millipore, Billerica, MA) in $5 \%$ normal goat serum overnight. The next day sections were incubated in biotinylated anti-rabbit IgG (1:500; Vector Laboratories, Burlingame, CA) for $1 \mathrm{~h}$ followed by avidin-biotin complex for $1 \mathrm{~h}$ (ABC Elite Kit, Vector Laboratories, Burlingame, CA). Cre immunoreactivity was visualized with $3,3^{\prime}$-diaminobenzidine.

\section{Warm Water Tail-Flick Assay}

The tail-flick assay was used to assess KOR-mediated analgesia (Janssen et al, 1963; McLaughlin et al, 2003). Mice were held by the scruff and their tails were submerged $1-2 \mathrm{~cm}$ in a $52 \pm 1{ }^{\circ} \mathrm{C}$ water bath. The latency for mice to withdraw their tail from the bath was timed with a stopwatch to establish baseline withdrawal latency. Mice were then given an intraperitoneal (IP) injection of the KOR agonist $( \pm) \mathrm{U} 50,488(15 \mathrm{mg} / \mathrm{kg})$ and withdrawal latencies were assessed 30 min later. A maximum tail immersion time of $15 \mathrm{~s}$ was used to prevent tissue damage.

\section{Acoustic Startle Response}

Acoustic startle data were collected by measuring the amplitude of the startle reflex in response to white noise bursts using the Med Associates (St Albans, VT) Startle Reflex System and Advanced Startle software program. Mice were placed into Plexiglas cages $(8.5 \times 7 \times 7 \mathrm{~cm})$ with steel rod floors attached to load cell platforms contained inside sound and light attenuating chambers $(40 \times 64 \times 42 \mathrm{~cm})$. The load cells are capable of transducing movement into an electrical output that is amplified and digitized into arbitrary units by an analog-to-digital converter interfaced to a personal computer. Startle amplitude was defined as the maximum peak-to-peak voltage occurring within the first $100 \mathrm{~ms}$ after the onset of the startle stimulus. An audio stimulator generated $40 \mathrm{~ms}$ startle stimuli $(1-32 \mathrm{kHz}$ white noise) that were delivered through speakers located behind the cages. To assess their startle threshold, mice were acclimated to the testing chamber for $5 \mathrm{~min}$ and then received 100 startle stimuli, 10 each at 70, 74, 78, 82, 86, 90, 94,98 , and $102 \mathrm{~dB}$ in a pseudo-random order with an interstimulus interval of 7-23 s (average of $15 \mathrm{~s}$ ).

\section{Weight}

To determine if KOR deletion alters body weight, individual mice were weighed at weekly intervals beginning at weaning (4 weeks) and continuing until adulthood (8 weeks). The same scale was used throughout the experiment and mice were only included if their exact date of birth was known. Weights were recorded to $0.1 \mathrm{~g}$.

\section{Visual Cliff}

Depth perception (visual acuity) was tested in the visual cliff paradigm. The apparatus consisted of a platform $1 \mathrm{~m}$ above the ground with a checkered pattern. A clear piece of Plexiglas was placed on the platform and extended $0.5 \mathrm{~m}$ beyond the platform edge. The checkered pattern was also placed on the floor below the extending Plexiglas, giving the illusion of an edge. At this interface was a smooth beam $(2.54 \times 2.54 \mathrm{~cm})$ running the length of the edge. Mice were placed on the beam and allowed to step off to either side. Choices were recorded as safe if the mouse stepped towards the platform side and unsafe if the mouse chose the overhang side. Each mouse was tested for 10 trials.

\section{Light/Dark Box Test}

The light/dark box test was used as a secondary method of quantifying anxiolytic-like effects only when data from the open field suggested group differences in Center Time. New cohorts of mice were used. The apparatus was based on published designs (Crawley, 2007) and consisted of a box $(42 \times 42 \times 30 \mathrm{~cm})$, one third of which was the dark compartment (2lux) and two thirds of which was the light compartment (380lux). An opening $(10 \times 5 \mathrm{~cm})$ allowed passage between the two sides. Mice were placed into the dark compartment and allowed to move freely in the apparatus for $5 \mathrm{~min}$. The latency for mice to transition from the dark chamber to the light chamber and the total time in the light chamber was recorded with EthoVision XT (Noldus Information Technology, Wageningen, the Netherlands). The apparatus was cleaned with $70 \%$ isopropyl alcohol between mice.

\section{EPM}

Mice that were tested in the light/dark box were also tested 7 days later in the EPM. Mice were tested on a plus maze $(75 \times 75 \mathrm{~cm})$ that was elevated $1 \mathrm{~m}$ above the floor. Each arm was $35 \times 6 \mathrm{~cm}$ connected by a $5 \times 5 \mathrm{~cm}$ center area. Mice were transferred to the dimly lit testing room at least $1 \mathrm{~h}$ before testing. Mice were placed onto the center of the apparatus facing a closed arm and activity was recorded for 5 min using EthoVision XT. Total time spent in the open arms and total distance traveled $(\mathrm{cm})$ were quantified. The maze was cleaned with $70 \%$ isopropyl alcohol between mice.

\section{Activity Testing}

To determine if KOR deletion alters overall locomotor activity, mice were tested in clear Plexiglas open field arenas $(28 \times 28 \times 20 \mathrm{~cm})$ housed inside light and sound attenuating chambers (Med Associates). Locomotor activity was 
quantified using an automated system equipped with infrared beams. Beam breaks were recorded and converted into horizontal distance traveled (Activity Monitor 5.0; Med Associates). The testing period was $1 \mathrm{~h}$. The amount of time mice spent in the $16 \times 16 \mathrm{~cm}$ interior of the open field (Center Time), a metric increased by drugs with anxiolytic effects in people (Prut and Belzung, 2003; Knoll et al, 2007), was also quantified.

\section{Cocaine Sensitization}

The cocaine locomotor sensitization test paradigm began immediately after the initial $1 \mathrm{~h}$ activity test. The methods were based on those previously described (Chefer et al, 2005) to enable direct comparisons between our mutant lines and published data. Briefly, at the same time each day mice were subjected to a $3 \mathrm{~h}$ test, which included a $1 \mathrm{~h}$ habituation session $(0-60 \mathrm{~min})$, a $1 \mathrm{~h}$ postsaline $(10 \mathrm{ml} / \mathrm{kg}$, IP) test session (60-120 min), and a final $1 \mathrm{~h}$ postcocaine (15 mg/kg, IP) test session (120-180 min). This procedure was repeated daily for 5 consecutive days followed by 2 days off and a final identical test on day 8 .

\section{Cocaine Place Conditioning}

The unbiased place conditioning apparatus consisted of opaque Plexiglas chambers with two interchangeable and distinct tactile floor stimuli (hole $v s$ grid), with which cocaine or vehicle injections were paired. Each chamber included a removable guillotine door that allowed the confinement of mice to one half of the apparatus. The experiments proceeded in three phases: habituation (one session), conditioning (four sessions; two conditioned stimulus (CS) + and two $\mathrm{CS}-$ ), and preference testing (one session). The habituation session was intended to reduce the novelty of the experimental apparatus and injection procedures. On the first day of the experiment, mice were injected with vehicle just before being placed in the conditioning chamber for $30 \mathrm{~min}$, where the floor was lined with smooth Plexiglas and the entire apparatus was open for exploration. During the conditioning phase, mice were injected with vehicle (morning session) or cocaine (afternoon session; 1.25 or $5 \mathrm{mg} / \mathrm{kg}$ ) just before being confined to one side of the conditioning chamber for $30 \mathrm{~min}$. Treatment conditions were randomly assigned and counterbalanced across genotypes. After two conditioning trials (two saline, two cocaine; Days 2-3), a 30-min preference test was conducted (Day 4) wherein the test floor was half hole and half grid and the entire apparatus was open for exploration. All conditioning and testing was conducted under dim light and scored using an automated system (EthoVision XT). Percent time in the drug-paired side was calculated based on the automated output. The apparatus was cleaned with $70 \%$ isopropyl alcohol between mice.

\section{Data Analysis}

All data are graphed as mean plus SEM. Data for each genotype were analyzed by two-sample $t$-tests or ANOVA followed by Bonferroni post hoc tests as appropriate. For the visual cliff and place conditioning experiments, one-sample $t$-tests were used to compare the observed data for each genotype to the hypothetical data expected for blind mice or lack of cocaine preference, respectively. Startle threshold was calculated as the lowest $\mathrm{dB}$ significantly different from no stimulation response using separate ANOVAs for each genotype.

\section{RESULTS}

Radioligand binding of $\left[{ }^{3} \mathrm{H}\right] \mathrm{U} 69,593$ was used to determine whether the floxed construct was effective in eliminating functional KORs in KOR-mutant mice. No detectable $\left[{ }^{3} \mathrm{H}\right] \mathrm{U} 69,593$ binding was present in $\mathrm{KOR}^{-1-}$ mice, whereas autoradiographic mapping in WT littermates showed clear distribution of KORs throughout the brain, including the NAc, AMY, and cortex (Figure 2b). The distribution is similar to those reported previously (reviewed in Mansour et al, 1988). Quantification demonstrated a significant difference in $\left[{ }^{3} \mathrm{H}\right] \mathrm{U} 69,593$ binding in brain areas of the mesocorticolimbic DA system (PFC, NAc, $\mathrm{CPu}, \mathrm{AMY}, \mathrm{VTA}$, and $\mathrm{SN}$ ), depicted in Figure 2a. Binding in $\mathrm{KOR}^{-1-}$ mice was reduced to background levels in all regions analyzed $(P<0.05$; Figure $2 \mathrm{~d})$. $\left[{ }^{3} \mathrm{H}\right] \mathrm{U} 69,593$ binding was visibly similar in both DAT-KOR ${ }^{\text {lox/lox }}$ mice and littermates $\left(\mathrm{KOR}^{\mathrm{lox} / \mathrm{lox}}\right)$ (Figure $2 \mathrm{c}$ ), but quantification showed that DAT-KOR ${ }^{\text {lox/lox }}$ mice had reduced binding in the PFC and $\mathrm{CPu}\left(P^{\prime} s<0.05\right.$; Figure 2e). While autoradiography cannot distinguish between KOR binding in DA and non-DA neurons, these reductions are consistent with the hypothesis that KORs would be ablated in regions of the midbrain DA system. KORs expressed on dopaminergic neurons represent only a fraction of total KORs within these areas, and KORs expressed in non-dopaminergic cells would not be affected in DAT-KOR ${ }^{\text {lox/lox }}$ mice. As such, complete ablation of KORs would not be expected in this line.

To further confirm the specificity of the deletion, brain dissections (punches) were analyzed by qPCR to quantify mRNA levels. We verified this technique by examining KOR and DAT mRNA in $\mathrm{KOR}^{-1-}$ mice (gene $\times$ genotype interaction, $\mathrm{F}[2,9]=39.94, P<0.0001)$. Post hoc analysis revealed reduced levels of KOR mRNA in heterozygotes and no detectable mRNA in $\mathrm{KOR}^{-1-}$ mice compared with $\mathrm{KOR}^{+1+}$ controls (Figure $3 \mathrm{a}$ ). The accuracy of the brain punches was verified through analysis of DAT mRNA, which showed similar levels among the genotypes. KOR mRNA levels were reduced in the VTA/SN of DAT-KOR ${ }^{\text {lox/lox }}$ mice compared with littermate controls, whereas DAT mRNA levels were not significantly different (gene $\times$ genotype interaction, $\mathrm{F}[1,6]=20.35, P<0.01$; Figure $3 \mathrm{~b}$ ). As expected based on the location of Cre expression (Figure 4), this reduction was specific to the VTA/SN and was not observed in other brain regions (region $\times$ genotype interaction, $\mathrm{F}[3,18]=8.10, P<0.01$; Figure $3 \mathrm{c}$ ).

Because KOR activation induces analgesia, the tail-flick assay was used as a behavioral confirmation of KOR deletion. Baseline tail withdrawal latencies did not differ between $\mathrm{KOR}^{-1-}$ or DAT-KOR ${ }^{\text {lox/lox }}$ mice and their littermate controls (Figure $5 \mathrm{a}, \mathrm{b}$ ). In $\mathrm{KOR}^{-1-}$ mice, tail withdrawal latencies depended upon a drug $\times$ genotype interaction $(\mathrm{F}[1,31]=24.23, \quad P<0.0001 ;$ Figure 5a). After U50,488 treatment $(15 \mathrm{mg} / \mathrm{kg}, \mathrm{IP}), \mathrm{KOR}^{+9+}$ mice had an increased tail withdrawal latency compared with their own baseline 

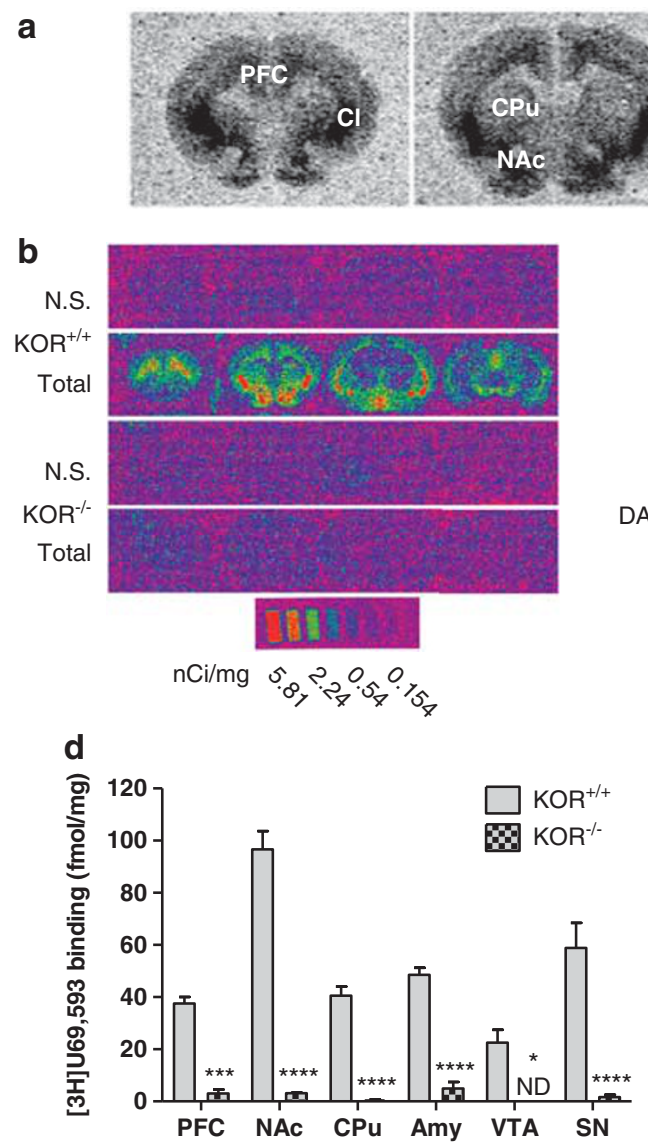

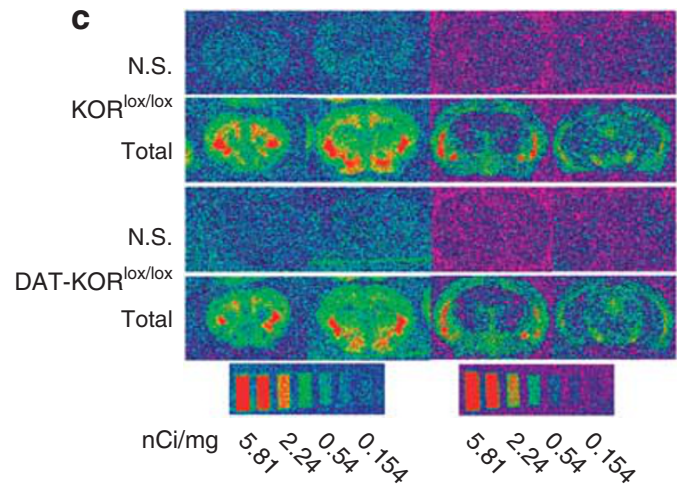

e

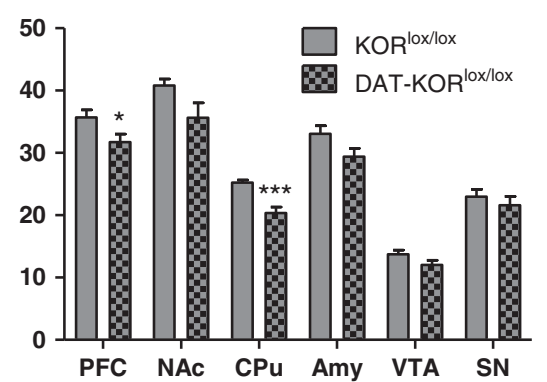

Figure $\left.2{ }^{3} \mathrm{H}\right] \cup 69,593$ binding in KOR knockout lines. (a) Representative autoradiograms of $\left[{ }^{3} \mathrm{H}\right] \cup 69,593$ binding to KORs in coronal brain sections of a $\mathrm{KOR}^{+1+}$ mouse at four different levels from rostral to caudal positions depicting regions of interest quantified in (d, e). (b, c) Representative computergenerated pseudocolor autoradiograms of $\left.{ }^{3} \mathrm{H}\right] \mathrm{U} 69,593$ binding in $\mathrm{KOR}^{+/+}, \mathrm{KOR}^{-{ }^{-}}, \mathrm{KOR}^{\text {lox/lox }}$, and DAT-KOR ${ }^{\text {lox/lox }}$ mice. Non-specific binding (N.S.) was assessed in the presence of naloxone. Note that exposure of sections to different screens yields slightly different signals, which were then calibrated with the corresponding microscale standards. (d, e) Quantification of specific $\left[{ }^{3} \mathrm{H}\right] \mathrm{U} 69,593$ binding (fmol/mg tissue) from brain regions known to express KORs. *P $<0.05$, **** $P<0.00$ I, ******* $P<0.000$ I $(n=3-6)$. AMY, amygdala; CPu, caudate putamen; NAc, nucleus accumbens; PFC, prefrontal cortex; SN, substantia nigra; VTA, ventral tegmental area.

$(P<0.0001)$ and significantly longer latencies than $\mathrm{KOR}^{-1-}$ mice $(P<0.0001)$. The response to U50,488 was similar to that observed in WT mice (increased latency compared with baseline) in DAT-KOR ${ }^{\text {lox/lox }}$ mice and did not differ comparedwith littermate controls (main effect of drug, $F[1,21]=24.92, P<0.0001$; Figure $5 \mathrm{~b}$ ), suggesting that DAT-expressing cells make a minimal contribution to the antinociceptive effects of KOR agonists. While some differences in the baseline and drug responses were noted between the mutant strains, this likely represented variability between the individual experiments, as all mice within each experiment were tested on the same day.

Both strains of the mutant mice appeared normal upon gross examination. Regardless, a series of experiments were conducted to determine whether their basic development and senses were intact. Mice were weighed weekly from age 4 to 8 weeks (Figures $6 \mathrm{a}$ and d) and analysis of mean body weight by time and genotype revealed a main effect of weight over time $(\mathrm{F}[4,84]=388.40, \quad P<0.0001$; $\mathrm{F}[4,64]=535.70, P<0.0001)$; however, both mutants were virtually indistinguishable from their littermate controls. To determine if hearing was affected in KOR-deficient mice, startle threshold was determined in both lines (Figures $6 \mathrm{~b}$ and e). Startle amplitude increased with increasing sound intensity $(\mathrm{dB})$ but did not differ significantly between control and mutant mice in either line. To calculate startle threshold, each genotype was analyzed separately. The lowest sound intensity tested that was significantly different from no stimulation controls was $86 \mathrm{~dB}$ in all groups indicating similar thresholds in control and mutant mice. Vision was tested in the visual cliff paradigm (Figures $6 \mathrm{c}$ and f). The percent of safe choices over 10 trials was determined for each mouse. Mutant mice did not differ from controls, or show deficits in visual depth perception as indicated by percent safe choices significantly above chance $(50 \% ; P<0.01)$. This is consistent with other studies in sighted mice, and in contrast to the random (52\% safe) choices made by a blind strain of mice $(\mathrm{C} 3 \mathrm{H} / \mathrm{HeJ}$; Fox, 1965). Overall, these data indicate that neither constitutive nor DA neuron-selective KOR deletion has an effect on body weight or basic sensory functions such as hearing or vision.

Activity testing also did not reveal any differences between mutant mice and controls (Figures $7 a$ and $c$ ). A more detailed analysis of the activity data suggested some strain differences in time spent in the center of the open 
a

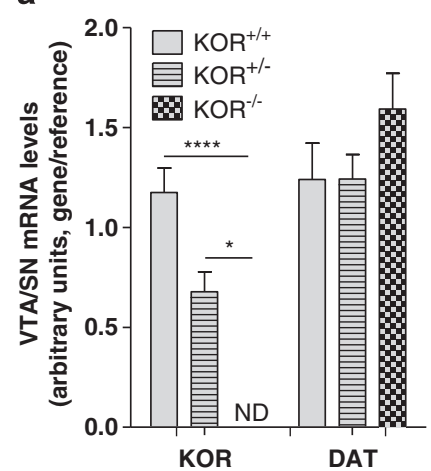

b

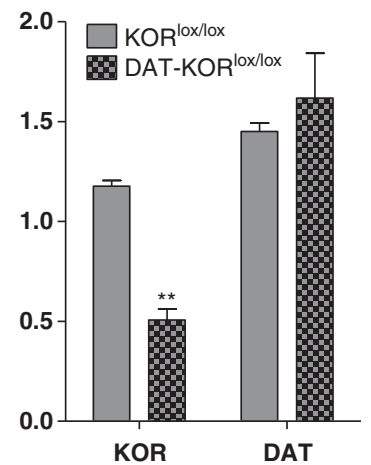

C

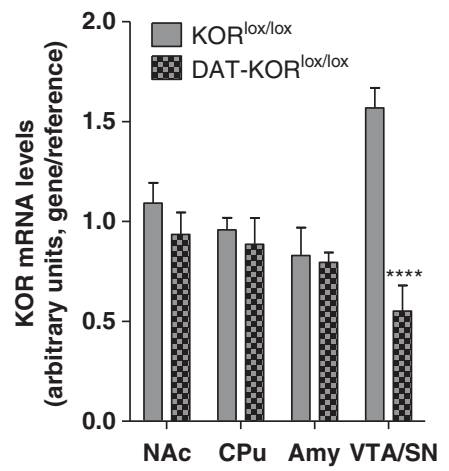

Figure 3 Gene expression analysis using qPCR in KOR-mutant mice. (a) Levels of KOR mRNA from punches of the ventral tegmental area and substantia nigra (VTA/SN) of mutant mice indicates reduced KOR mRNA in $\mathrm{KOR}^{-1+}$ mice and no detectable levels in $\mathrm{KOR}^{-1-}$ mice compared with controls. (b) Similarly, DAT-KOR ${ }^{\text {lox/lox }}$ mice have significantly less KOR mRNA than KOR ${ }^{\text {lox/lox }}$ littermates. Levels of DAT mRNA were equivalent in mutants and controls. (c) KOR mRNA reductions were specific for the VTA/SN in DAT-KOR ${ }^{\text {lox lox }}$ knockouts. $* P<0.05, * * P<0.0$ I, ***** $P<0.000$ I $(n=4)$.

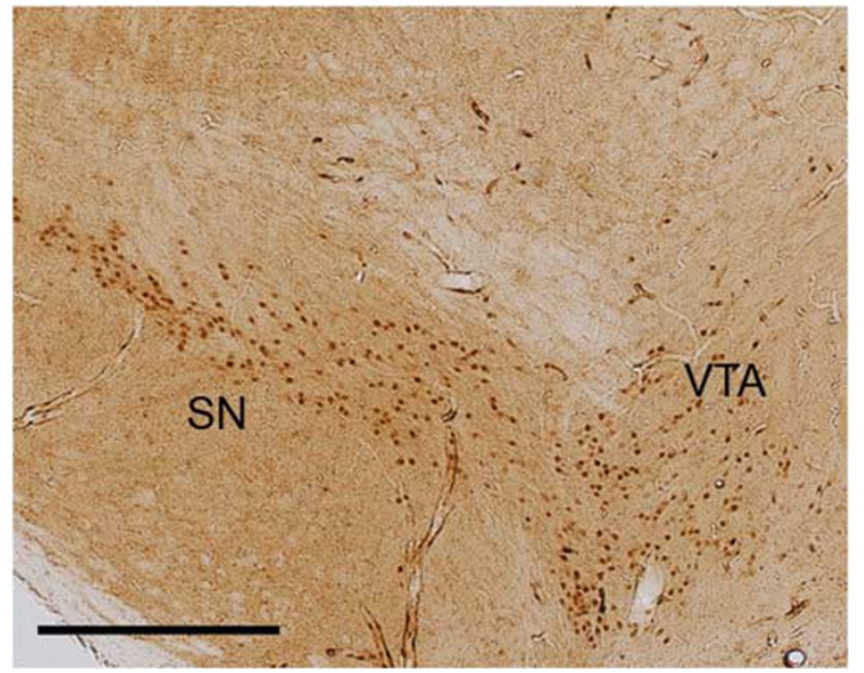

Figure 4 Immunohistochemistry for Cre. DAT-KOR ${ }^{\text {lox/lox }}$ mice show Cre immunoreactivity specifically in the VTA and SN. Scale bar indicates $400 \mu \mathrm{m}$.
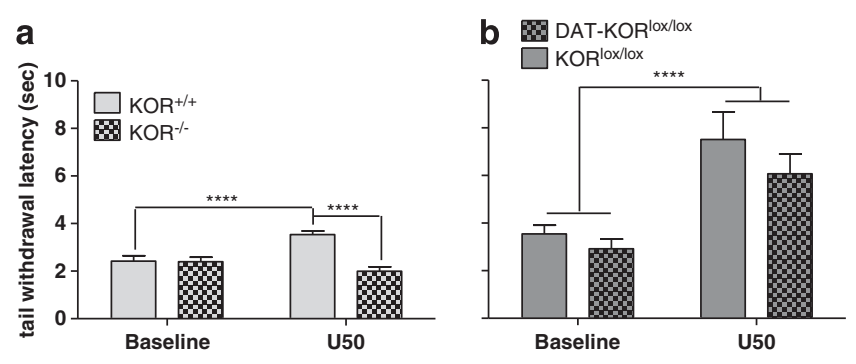

Figure 5 Warm water tail-flick assay at baseline and $30 \mathrm{~min}$ following the $\mathrm{KOR}$ agonist $U 50,488(15 \mathrm{mg} / \mathrm{kg}, \mathrm{IP})$. (a) U50,488 induced analgesia in $\mathrm{KOR}^{+\rho+}$ but not $\mathrm{KOR}^{-1-}$ mice. (b) U50,488 significantly increased tail withdrawal latencies in both $\mathrm{KOR}^{\text {lox/lox }}$ and DAT-KOR $\mathrm{R}^{\text {lox/lox }}$ knockouts. ******* $P<0.000$ I $(n=\mid 1-17)$.

field. Although there were no significant differences in Center Time when the entire 60-min test period was analyzed (not shown), visual inspection of the data indicated high variability during the first $15 \mathrm{~min}-\mathrm{a}$ time during which mice were most actively exploring the new environment-followed by a 45-min period during which group differences emerged. As such, we reanalyzed the Center Time data using only the final $45 \mathrm{~min}$ of the test session. Under these conditions, $\mathrm{KOR}^{-1-}$ mice were similar to WT controls in Center Time (main effect of time, $\mathrm{F}[2,28]=6.48, P<0.01$; Figure 7b). However, DAT$\mathrm{KOR}^{\text {lox/lox }}$ mice spent considerably more time in the center of the open field (main effect of genotype, $\mathrm{F}[1,32]=5.45$, $P<0.05$; Figure $7 \mathrm{~d}$ ), an anxiolytic-like effect. To determine whether these mice would show less anxiety-like behavior in other paradigms, DAT-KOR ${ }^{\text {lox/lox }}$ mice were tested in the light/dark box and EPM. DAT-KOR ${ }^{\text {lox/lox }}$ mice had significantly shorter latencies to enter the light side of the light/dark box $(P<0.05$, anxiolytic-like effect; Figure 8a), although once making this transition the total time in the light side did not differ between genotypes (Figure $8 \mathrm{~b}$ ). Open field and light/dark box effects were not attributable to the expression of Cre-recombinase alone, as DAT-KOR ${ }^{+/+}$ mice did not differ from $\mathrm{KOR}^{+/+}$littermate controls (data not shown). No differences were detected in open arm time or open arm entries in the EPM (Figures $8 \mathrm{c}$ and $\mathrm{d}$ ).

Previous results suggest that $\mathrm{KOR}^{-1-}$ mice fail to exhibit cocaine-induced behavioral sensitization, but appear presensitized to the locomotor-activating effects following the first injection of cocaine (Chefer et al, 2005). To determine whether our lines of mice-which differ from these previous lines because they were generated by loxP recombination-exhibit a similar behavioral phenotype, mice were tested in a cocaine-induced behavioral sensitization paradigm. Both $\mathrm{KOR}^{-1-}$ mice and $\mathrm{KOR}^{+/+}$ littermates developed locomotor sensitization to cocaine $(15 \mathrm{mg} / \mathrm{kg}, \mathrm{IP})$ and did not significantly differ from one another (Figures 9a-c). Analysis of distance traveled in $1 \mathrm{~h}$ following cocaine treatment revealed a main effect of day $(\mathrm{F}[5,70]=12.11, P<0.0001$; Figure 9c), but no interaction with genotype. Because behavioral sensitization may involve changes in DA function (Koff et al, 1994; Valjent et al, 2010), mutant mice lacking KORs specifically in DATexpressing neurons were also tested. Both DAT-KOR ${ }^{\text {lox/lox }}$ mice and littermate controls exhibited locomotor sensitization to daily injections of cocaine, although the degree of sensitization was enhanced in the mutants, and depended upon a genotype $\times$ treatment day interaction $(F[5,80]=2.64$, 

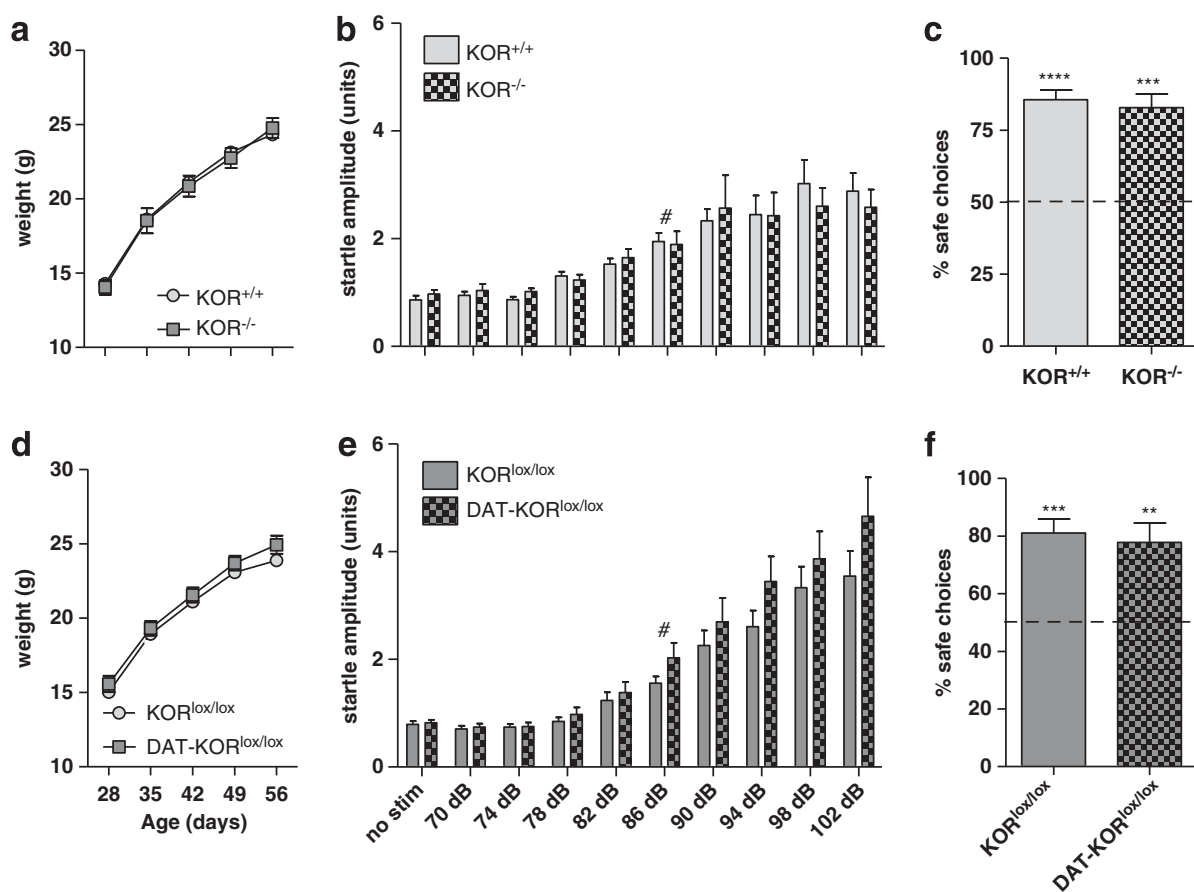

Figure 6 Effects of KOR deletion on weight gain and sensory function. (a, d) Weight gain in knockout mice did not differ from littermate controls. $(n=9-$ 14) (b, e). Startle responding in knockout mice did not statistically differ from controls. Hearing thresholds for all genotypes was $86 \mathrm{~dB}$. ( $n=8-10)$ (c, $\mathrm{f}$ ). Vision was not affected in either KOR-mutant line. $(n=7-9){ }^{\#} P<0.05$ compared with no stimulation (no stim) condition. Each genotype was analyzed individually. $* * * 0.01$, **** $P<0.001$, ***** $P<0.000$ I compared with $50 \%$.
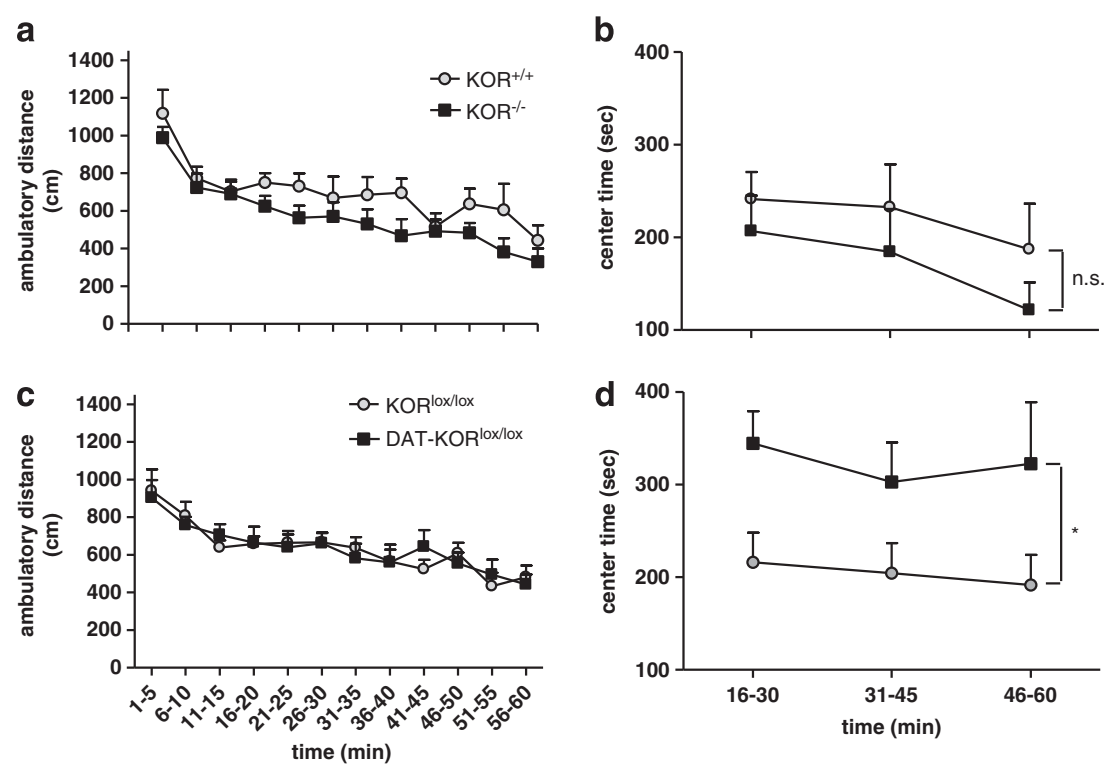

Figure 7 Open field activity. (a, c) General locomotor behavior was unchanged by KOR deficiency. (b) Time spent in the center of the open field was not significantly different between $\mathrm{KOR}^{+1+}$ and $\mathrm{KOR}^{-1-}$ mice. (d) DAT-KOR ${ }^{\text {loxlox }}$ mice spent significantly more time in the center than $\mathrm{KOR}^{\text {lox/lox }}$ littermates. $* P<0.05(n=8-9)$.

$P<0.05$; Figures $10 \mathrm{a}-\mathrm{c})$. Post hoc analysis at each day of testing indicated that DAT-KOR ${ }^{\text {lox/lox }}$ mice had a significantly greater response to cocaine at day 8 compared with littermate controls $(P<0.05$; Figure 10c). Control mice expressing DAT-Cre with WT KOR alleles (ie, lacking loxP sites; DAT-KOR $\left.{ }^{+1+}\right)$ and their littermate controls $\left(\mathrm{KOR}^{+1+}\right)$ were tested separately. Cre expression alone was not sufficient to increase sensitization (data not shown).
To determine whether the DAT-KOR ${ }^{\text {lox/lox }}$ mice would also exhibit enhanced effects in other cocaine-induced behaviors, mutant mice were tested in a cocaine conditioned place preference paradigm. Mice were first tested with two conditioning trials of $5 \mathrm{mg} / \mathrm{kg}$ cocaine, the minimum dose we have found to be effective at producing place preference in mice (A Van't Veer and AJ Bechtholt, unpublished observations). At this dose, both genotypes 

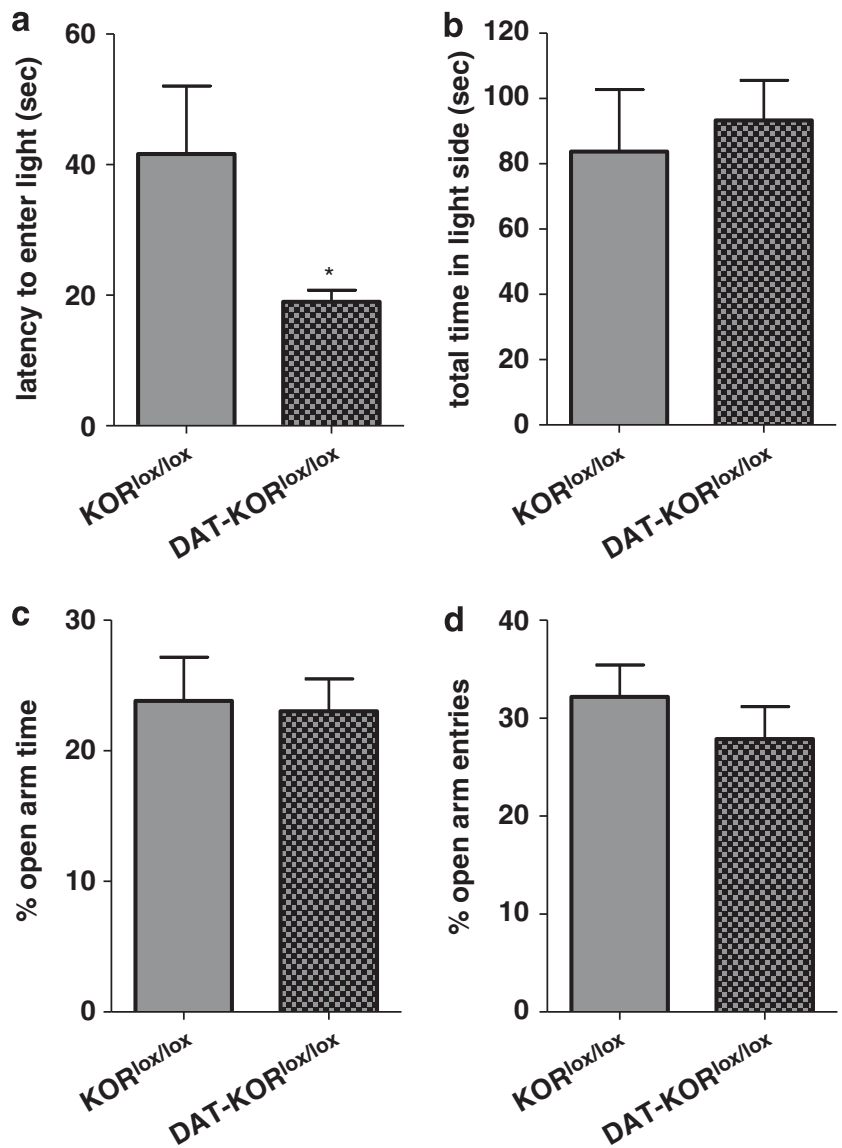

Figure 8 Effects of KOR ablation in DA neurons on light/dark box and EPM behaviors. (a) DAT-KOR ${ }^{\text {lox/lox }}$ mice had reduced latencies to first enter the light compartment compared with KOR ${ }^{\text {lox/lox }}$ controls. (b). No differences were observed in total time spent in the light compartment. (c, d) In the EPM, DAT-KOR ${ }^{\text {lox/lox }}$ mice did not differ from KOR ${ }^{\text {lox/lox }}$ controls in the percent time spent in the open arms or percent open arm entries. $* P<0.05(n=|0-| \mid)$.

displayed a significant preference for the drug-paired side in contrast to the expected observation of equal time spent on both sides of the apparatus if no preference was formed $(P<0.01$; Figure 11a) and were not different from each other. To determine if a lack of difference in genotypes was due to a ceiling effect on preference, a lower dose of cocaine $(1.25 \mathrm{mg} / \mathrm{kg})$ was used in a follow-up experiment. It was predicted that if DAT-KOR ${ }^{\text {lox/lox }}$ mice were more sensitive to the effects of cocaine, the drug might establish a place preference at a dose too low to induce preference in WT mice. However, $1.25 \mathrm{mg} / \mathrm{kg}$ cocaine did not establish place preferences in either genotype, as indicated by virtually equal amounts of time spent in both sides of the testing apparatus (Figure 11b).

\section{DISCUSSION}

Here we describe the development of two lines of mice with mutations in KOR systems: a constitutive line $\left(\mathrm{KOR}^{-1-}\right)$, in which KORs are ablated throughout body, and a conditional line (DAT-KOR ${ }^{\text {lox/lox }}$ ), in which KORs are lacking in DA-expressing cells. Autoradiography studies confirmed loss of functional KOR protein, as reflected by
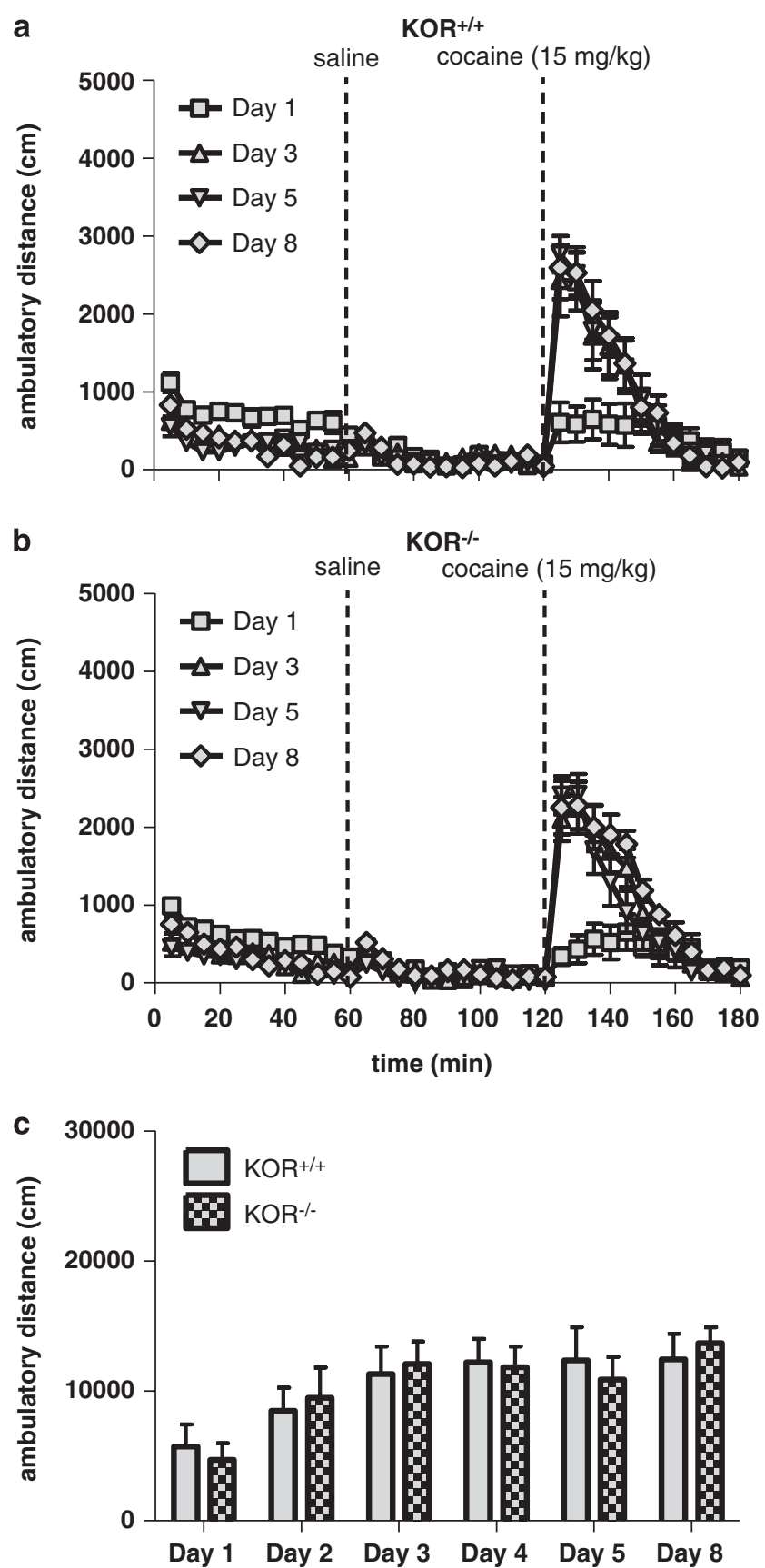

Figure 9 Cocaine-induced locomotor sensitization in $\mathrm{KOR}^{-1-}$ mice. $\mathrm{KOR}^{-1-}$ mice were not significantly different from $\mathrm{KOR}^{+1+}$ littermates. $(\mathrm{a}, \mathrm{b})$ Time course of ambulatory distance $(\mathrm{cm})$ in $\mathrm{KOR}^{+1+}$ and $\mathrm{KOR}^{-1-}$ mice during the first I h of testing and following injection of saline $(10 \mathrm{ml} /$ $\mathrm{kg})$ and cocaine $(15 \mathrm{mg} / \mathrm{kg})$. Time of injection is indicated by a dotted line. (c) Sum of the distance traveled during the I h test period following cocaine injection for each test day $(n=8)$.

binding of the highly selective KOR agonist $\left[{ }^{3} \mathrm{H}\right] \mathrm{U} 69,593$. Binding of this ligand was completely absent in the $\mathrm{KOR}^{-9_{-}}$mice and, as expected, reduced in the DAT$\mathrm{KOR}^{\text {lox/lox }}$ mice in brain areas rich in DA cell bodies or terminals while appearing intact in other brain areas. To complement these protein analyses, we used qPCR to confirm loss of KOR gene expression throughout the brain in the $\mathrm{KOR}^{-1-}$ mice and in midbrain DA systems 

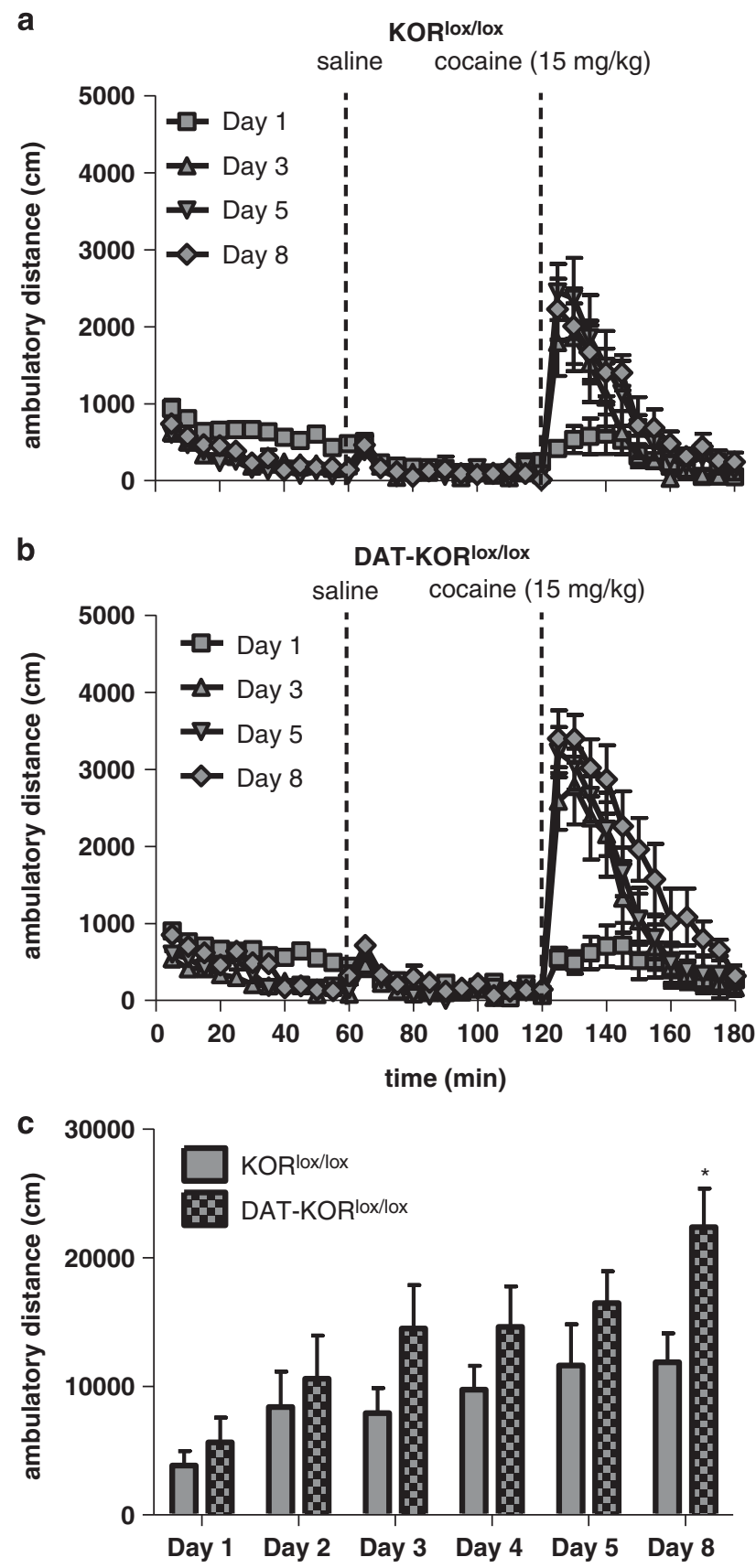

Figure 10 Cocaine-induced locomotor sensitization in DAT-KOR ${ }^{\text {lox/lox }}$ mice. DAT-KOR ${ }^{\text {lox/lox }}$ mice had greater locomotor sensitization to cocaine than $\mathrm{KOR}^{\text {lox/lox }}$ littermate controls. (a, b) Time course of ambulatory distance $(\mathrm{cm})$ in $\mathrm{KOR}^{\mathrm{lox} / \mathrm{lox}}$ and DAT-KOR $\mathrm{R}^{\text {lox/lox }}$ mice during the first I $\mathrm{h}$ of testing and following injection of saline $(10 \mathrm{ml} / \mathrm{kg})$ and cocaine $(15 \mathrm{mg} / \mathrm{kg})$. Time of injection is indicated by a dotted line. (c) Sum of the distance traveled during the $\mathrm{I} \mathrm{h}$ test period following cocaine injection for each test day. $* P<0.05(n=9)$.

of DAT-KOR ${ }^{\text {lox/lox }}$ mice. There is some evidence from binding studies suggesting the existence of KOR subtypes; however, ablation of the KOR gene eliminates all receptor function, suggesting that the subtypes are due to alternative splicing, heterodimerization with other classes of opioid receptors, or interactions with other proteins (Dietis et al, 2011). Thus, absence of U69,593 binding in our work,
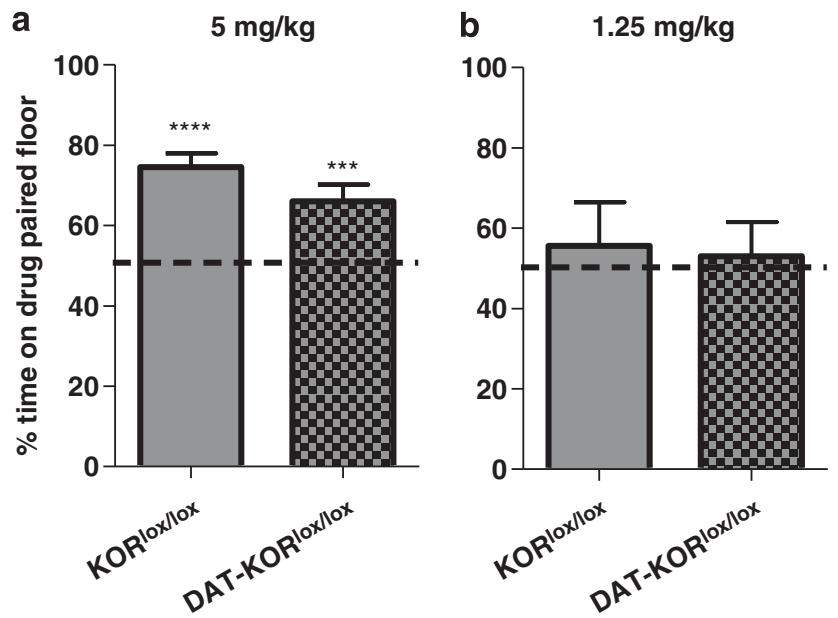

Figure II Cocaine-induced conditioned place preference. (a) Place preferences observed in $\mathrm{KOR}^{\text {lox/lox }}$ and DAT-KOR ${ }^{\text {lox/lox }}$ mice did not differ following conditioning with $5 \mathrm{mg} / \mathrm{kg}$ cocaine. (b) Neither genotype developed place preferences to $1.25 \mathrm{mg} / \mathrm{kg}$ cocaine. $* * * * P<0.00 \mathrm{I}$, ***** $P<0.000$ I compared with no preference (50\% time on drug-paired floor) $(n=9-10)$.

although KOR subtype 1-selective demonstrates lack of all KOR function.

In an in vivo test of KOR function, we found that the KOR agonist U50,488 was completely devoid of antinociceptive effects (McLaughlin et al, 2003) in the $\mathrm{KOR}^{-1-}$ mice. However, there was no such loss of function in the DAT$\mathrm{KOR}^{\text {lox/lox }}$ mice, suggesting that the antinociceptive effects of KOR agonists are not mediated by brain DA systems. We also tested these mouse lines in a broad battery of tests to quantify effects of these mutations on sensory function, growth, and locomotor activity. Compared with littermate controls, both lines of mice gained weight normally throughout development and neither line of mice showed any evidence of deficits in hearing, vision, or movement in an open field (eg, lethargy or gross motor abnormalities). Our findings suggest that the mutations we induced do not produce non-specific effects that can complicate data interpretation in tests where it is assumed that the mutants are normal in each of these domains.

While there were no differences in either strain in overall locomotor activity in the open field, a more detailed analysis in which activity patterns were quantified revealed some differences in the time spent in the center of the field (Center Time). These differences were seen only in DAT$\mathrm{KOR}^{\text {lox/lox }}$ mice; the $\mathrm{KOR}^{-/-}$mice did not differ from controls. Furthermore, Center Time differences were only statistically significant when data from the final $45 \mathrm{~min}$ of the test session were analyzed. The strategy of restricting data analysis to later portions of a test period is common in these types of screening procedures, especially in tests such as the forced swim test (Porsolt et al, 1977) where there is large variability or almost complete overlap among groups in the earliest portions of the test session. Regardless, DAT$\mathrm{KOR}^{\text {lox/lox }}$ mice spent considerably more time in the center of the open field. This type of pattern is often interpreted as reflecting an anxiolytic-like phenotype, as drugs with anxiolytic effects in humans produce this same effect on Center Time behavior (Prut and Belzung, 2003; Knoll et al, 
2007). Elevated Center Time in the KOR mutants is also broadly consistent with previous work indicating that KOR antagonists have anxiolytic-like effects in rodents (Knoll et al, 2007; Carr and Lucki, 2010; Rogala et al, 2012). To further assess the possibility that increased Center Time in the DAT-KOR ${ }^{\text {lox/lox }}$ mice reflects an anxiolytic-like phenotype, we tested additional (naive) cohorts of mice in the light/dark box test. Latencies to enter the light (ie, anxietyprovoking) side of the apparatus were significantly lower in the DAT-KOR ${ }^{\text {lox/lox }}$ mice, also suggesting an anxiolytic phenotype. However, upon entry, the mutant mice were just as likely to spend time in the light side as controls, suggesting reductions in passive avoidance behavior (latency to enter the light) rather than active avoidance behavior (tendency to escape from the light). The lack of an anxiolytic-like phenotype in the EPM is surprising, but this outcome may reflect the fact that these mice had been used previously in the light/dark box test, which may cause generalized reductions in anxiety-related behavior in subsequent tests. Lack of effects in the EPM may also reflect the fact that this test was developed to identify pharmacological treatments (eg, benzodiazepines) with anxiolytic effects (File, 1990; Haller et al, 2012), and may have a different threshold for identifying the more subtle effects of mutations. Lack of any evidence of an anxiolyticlike phenotype in the $\mathrm{KOR}^{-l-}$ mutants suggests more thorough compensatory adaptations occur after constitutive receptor ablation, or that under normal conditions activation of KORs in populations of non-DA neurons produce anxiolytic effects that offset the anxiogenic effects of KOR activation in DA-expressing neurons.

Although the $\mathrm{KOR}^{-1-}$ mice appeared to have normal sensitivity to the locomotor-stimulating effects of cocaine, the DAT-KOR ${ }^{\text {lox/lox }}$ mice had exaggerated sensitivity. This exaggerated sensitivity was most evident when cocaine had been given in a repeated, intermittent (daily) regimen, followed by a 2-day period of no treatment: a challenge dose of cocaine produced much greater forward locomotion in the DAT-KOR ${ }^{\text {lox/lox }}$ mice than in controls. The process of sensitization to the locomotor-activating effects of cocaine is often considered to be important because it is an example of cocaine-induced plasticity, and the neuroadaptations underlying this process may be related to those that contribute to addictive behaviors (Robinson and Berridge, 2000; Carlezon and Nestler, 2002). Considering that the locomotor-stimulating effects of drugs of abuse are strongly associated with their ability to elevate extracellular concentrations of DA in the NAc (Wise and Bozarth, 1987), these findings are consistent with the hypothesis that KORs provide negative regulation of the function of the mesocorticolimbic DA system (Carlezon et al, 2009). In this context, it is surprising that the $\mathrm{KOR}^{-I-}$ mice did not show exaggerated sensitization to cocaine, considering the fact that they also lack KOR regulation of mesocorticolimbic DA systems. In addition, it has been previously reported that a different line of $\mathrm{KOR}^{-1-}$ mice show exaggerated sensitization to the locomotor-stimulating effects of cocaine in a virtually identical treatment regimen (Chefer et al, 2005). While the line of mice used in those previous studies and our $\mathrm{KOR}^{-I-}$ mice both have constitutive receptor ablation, there are important differences, including the targeting vector and background flanking genes (Chefer et al, 2005).
Considering that the rewarding effects also undergo a process of sensitization with repeated exposure (Lett, 1989; Piazza et al, 1989; Shippenberg and Heidbreder, 1995), we tested additional (naive) cohorts of the DAT-KOR ${ }^{\text {lox/lox }}$ mice in the cocaine place conditioning test. These mice did not seem more sensitive to either a subthreshold dose of cocaine $(1.25 \mathrm{mg} / \mathrm{kg}$, IP) that does not establish a conditioned place preference in controls, or to a higher dose $(5.0 \mathrm{mg} / \mathrm{kg})$ that does establish a place preference in controls. Although these data may indicate that KORs have a more profound regulatory influence on the locomotorstimulating effects of cocaine than on its rewarding effects, this interpretation seems unlikely considering that KOR agonists are known to reduce the reward-related effects of cocaine (Tomasiewicz et al, 2008). Rather, this effect may be due to a relative lack of sensitivity of the place conditioning test to subtle differences in reward or that more drug exposure and/or a period of no treatment is needed to reveal differential sensitivity, as was the case in the locomotor sensitization studies. Indeed, a common criticism of place conditioning is that dose-effects are 'all or none' (Bevins, 2005), suggesting that doses of cocaine above $5.0 \mathrm{mg} / \mathrm{kg}$-including $15 \mathrm{mg} / \mathrm{kg}$ as used in sensitization studies-would establish qualitatively similar place preferences. We conducted pilot studies at $20 \mathrm{mg} / \mathrm{kg}$ cocaine and found that the magnitude of place preferences were virtually identical to those seen at $5.0 \mathrm{mg} / \mathrm{kg}$, with no differences between genotypes (A Van't Veer and A J Bechtholt, unpublished observations). Future studies that utilize other testing procedures, such as the intracranial self-stimulation (ICSS) test, may provide more insight on mutation-induced differences in sensitivity to cocaine and other drugs of abuse. Although the ICSS procedure is very time-consuming, it is minimally sensitive to learning deficits (Carlezon and Chartoff, 2007) and it has effectively identified mutation-related alterations in sensitivity to the rewardrelated effects of cocaine (Roybal et al, 2007; Dinieri et al, 2009; Muschamp et al, 2012).

These mouse lines may be useful in future studies of KOR function. As one example, these lines of mice could be bred with lines expressing ligand (eg, tamoxifen)-dependent Cre, such that the tissue selective gene excision can be induced at any time during development (Feil et al, 2009). Use of these mice would provide deeper insight on the development of long-term compensatory mechanisms that affect the phenotypes of the mutants. Similarly, viral vectors expressing Cre could be micro-infused into discrete brain areas (Berton et al, 2006; Graham et al, 2009), enabling an alternative method with which to accomplish time- and tissue-selective gene ablation. Viral vectors expressing KORs could also be used in the $\mathrm{KOR}^{-1-}$ mice to 'rescue' behavioral phenotypes or reestablish sensitivity to drugs that act at KORs. Such studies are beyond the scope of the present report, the goals of which were to characterize these mouse lines and to report the development of a novel in vivo tool that should be useful for studies modeling the etiology and treatment of psychiatric conditions ranging from depression and anxiety (Carlezon et al, 2009; Knoll and Carlezon, 2010) to addiction to substances including cocaine (McLaughlin et al, 2003; Beardsley et al, 2005; Bruchas et al, 2010; Wee and Koob, 2010), nicotine (Jackson et al, 2010), and ethanol (Walker et al, 2012). 


\section{ACKNOWLEDGEMENTS}

This research was supported by a National Defense Science and Engineering Graduate Fellowship (to AVV), the Frazier Medical Research Institute (to BMC), DA13429 (to L-Y L-C) and MH062366 (to WAC).

\section{DISCLOSURE}

Dr Carlezon has a US patent covering the use of kappa antagonists in the treatment of depression (Assignee: McLean Hospital). In the last 3 years Dr Carlezon has received compensation for professional services from The American College of Neuropsychopharmacology and Concert Pharmaceuticals. Dr Cohen has pending patents on pyrimidines to treat bipolar disorders, kappa-opioid agonists in bipolar mania, and on mitochondrial replacement. In the last 3 years, $\mathrm{Dr}$ Rudolph has provided professional services to Sunovion Pharmaceuticals and to Concert Pharmaceuticals. The other authors have no disclosures.

\section{REFERENCES}

Beardsley PM, Howard JL, Shelton KL, Carroll FI (2005). Differential effects of the novel kappa opioid receptor antagonist, JDTic, on reinstatement of cocaine-seeking induced by footshock stressors vs cocaine primes and its antidepressant-like effects in rats. Psychopharmacology 183: 118-126.

Berton O, McClung CA, Dileone RJ, Krishnan V, Renthal W, Russo $\mathrm{SJ}$ et al (2006). Essential role of BDNF in the mesolimbic dopamine pathway in social defeat stress. Science 311: 864-868.

Bevins RA (2005). The reference-dose place conditioning procedure yields a graded dose-effect function. Int J Comp Psychol 18: 101-111.

Bruchas MR, Chavkin C (2010). Kinase cascades and liganddirected signaling at the kappa opioid receptor. Psychopharmacology 210: 137-147.

Bruchas MR, Land BB, Chavkin C (2010). The dynorphin/kappa opioid system as a modulator of stress-induced and proaddictive behaviors. Brain Res 1314: 44-55.

Bruchas MR, Schindler AG, Shankar H, Messinger DI, Miyatake M, Land BB et al (2011). Selective p38alpha MAPK deletion in serotonergic neurons produces stress resilience in models of depression and addiction. Neuron 71: 498-511.

Carlezon WA Jr., Beguin C, DiNieri JA, Baumann MH, Richards MR, Todtenkopf MS et al (2006). Depressive-like effects of the kappa-opioid receptor agonist salvinorin A on behavior and neurochemistry in rats. J Pharmacol Exp Ther 316: 440-447.

Carlezon WA Jr., Beguin C, Knoll AT, Cohen BM (2009). Kappaopioid ligands in the study and treatment of mood disorders. Pharmacol Ther 123: 334-343.

Carlezon WA Jr., Carroll FI (2013). Development of kappa opioid receptor antagonists. J Med Chem; e-pub ahead of print 14 February 2013. doi:10.1021/jm301783x.

Carlezon WA Jr., Chartoff EH (2007). Intracranial self-stimulation (ICSS) in rodents to study the neurobiology of motivation. Nat Protoc 2: 2987-2995.

Carlezon WA Jr., Nestler EJ (2002). Elevated levels of GluR1 in the midbrain: a trigger for sensitization to drugs of abuse? Trends Neurosci 25: 610-615.

Carr GV, Lucki I (2010). Comparison of the kappa-opioid receptor antagonist DIPPA in tests of anxiety-like behavior between Wistar Kyoto and Sprague Dawley rats. Psychopharmacology 210: 295-302.
Chavkin C, James IF, Goldstein A (1982). Dynorphin is a specific endogenous ligand of the kappa opioid receptor. Science 215: 413-415.

Chefer VI, Czyzyk T, Bolan EA, Moron J, Pintar JE, Shippenberg TS (2005). Endogenous kappa-opioid receptor systems regulate mesoaccumbal dopamine dynamics and vulnerability to cocaine. J Neurosci 25: 5029-5037.

Cohen BM, Murphy B (2008). The effects of pentazocine, a kappa agonist, in patients with mania. Int J Neuropsychopharmacol 11: 243-247.

Crawley JN (2007). What's Wrong with My Mouse?: Behavioral Phenotyping of Transgenic and Knockout Mice. 2nd edn John Wiley: Hoboken.

Devine DP, Leone P, Pocock D, Wise RA (1993). Differential involvement of ventral tegmental $\mathrm{mu}$, delta and kappa opioid receptors in modulation of basal mesolimbic dopamine release: in vivo microdialysis studies. J Pharmacol Exp Ther 266: 1236-1246.

Di Chiara G, Imperato A (1988). Opposite effects of mu and kappa opiate agonists on dopamine release in the nucleus accumbens and in the dorsal caudate of freely moving rats. J Pharmacol Exp Ther 244: 1067-1080.

Dietis N, Rowbotham DJ, Lambert DG (2011). Opioid receptor subtypes: fact or artifact? Br J Anaesth 107: 8-18.

Dinieri JA, Nemeth CL, Parsegian A, Carle T, Gurevich VV, Gurevich E et al (2009). Altered sensitivity to rewarding and aversive drugs in mice with inducible disruption of cAMP response element-binding protein function within the nucleus accumbens. J Neurosci 29: 1855-1859.

Donzanti BA, Althaus JS, Payson MM, Von Voigtlander PF (1992). Kappa agonist-induced reduction in dopamine release: site of action and tolerance. Res Commun Chem Pathol Pharmacol 78: 193-210.

Feil S, Valtcheva N, Feil R (2009). Inducible Cre mice. Methods Mol Biol 530: 343-363.

File SE (1990). New strategies in the search for anxiolytics. Drug Des Deliv 5: 195-201.

Ford CP, Beckstead MJ, Williams JT (2007). Kappa opioid inhibition of somatodendritic dopamine inhibitory postsynaptic currents. J Neurophysiol 97: 883-891.

Fox MW (1965). The visual cliff test for the study of visual depth perception in the mouse. Anim Behav 13: 232-233.

Graham DL, Krishnan V, Larson EB, Graham A, Edwards S, Bachtell RK et al (2009). Tropomyosin-related kinase B in the mesolimbic dopamine system: region-specific effects on cocaine reward. Biol Psychiatry 65: 696-701.

Haller J, Aliczki M, Gyimesine Pelczer K (2012). Classical and novel approaches to the preclinical testing of anxiolytics: A critical evaluation. Neurosci Biobehav Rev; epub ahead of print 12 September 2012. doi:10.1016/j.neubiorev.2012.09.001.

Inan S, Cowan A (2004). Kappa opioid agonists suppress chloroquine-induced scratching in mice. Eur J Pharmacol 502: 233-237.

Jackson KJ, Carroll FI, Negus SS, Damaj MI (2010). Effect of the selective kappa-opioid receptor antagonist JDTic on nicotine antinociception, reward, and withdrawal in the mouse. Psychopharmacology 210: 285-294.

Janssen PA, Niemegeers CJ, Dony JG (1963). The inhibitory effect of fentanyl and other morphine-like analgesics on the warm water induced tail withdrawl reflex in rats. Arzneimittelforschung 13: 502-507.

Knoll AT, Carlezon WA Jr. (2010). Dynorphin, stress, and depression. Brain Res 1314: 56-73.

Knoll AT, Meloni EG, Thomas JB, Carroll FI, Carlezon WA Jr. (2007). Anxiolytic-like effects of kappa-opioid receptor antagonists in models of unlearned and learned fear in rats. J Pharmacol Exp Ther 323: 838-845.

Koff JM, Shuster L, Miller LG (1994). Chronic cocaine administration is associated with behavioral sensitization and time-dependent 
changes in striatal dopamine transporter binding. J Pharmacol Exp Ther 268: 277-282.

La Regina A, Petrillo P, Sbacchi M, Tavani A (1988). Interaction of U-69,593 with mu-, alpha- and kappa-opioid binding sites and its analgesic and intestinal effects in rats. Life Sci 42: 293-301.

Lett BT (1989). Repeated exposures intensify rather than diminish the rewarding effects of amphetamine, morphine, and cocaine. Psychopharmacology 98: 357-362.

Maisonneuve IM, Archer S, Glick SD (1994). U50,488, a kappa opioid receptor agonist, attenuates cocaine-induced increases in extracellular dopamine in the nucleus accumbens of rats. Neurosci Lett 181: 57-60.

Mansour A, Khachaturian H, Lewis ME, Akil H, Watson SJ (1988). Anatomy of CNS opioid receptors. Trends Neurosci 11: 308-314.

Margolis EB, Hjelmstad GO, Bonci A, Fields HL (2003). Kappaopioid agonists directly inhibit midbrain dopaminergic neurons. J Neurosci 23: 9981-9986.

Margolis EB, Lock H, Chefer VI, Shippenberg TS, Hjelmstad GO, Fields HL (2006). Kappa opioids selectively control dopaminergic neurons projecting to the prefrontal cortex. Proc Natl Acad Sci USA 103: 2938-2942.

McLaughlin JP, Marton-Popovici M, Chavkin C (2003). Kappa opioid receptor antagonism and prodynorphin gene disruption block stress-induced behavioral responses. J Neurosci 23: 5674-5683.

Muschamp JW, Nemeth CL, Robison AJ, Nestler EJ, Carlezon WA Jr. (2012). DeltaFosB enhances the rewarding effects of cocaine while reducing the pro-depressive effects of the kappa-opioid receptor agonist U50488. Biol Psychiatry 71: 44-50.

Parlato R, Rieker C, Turiault M, Tronche F, Schutz G (2006). Survival of DA neurons is independent of CREM upregulation in absence of CREB. Genesis 44: 454-464.

Pasternak GW (1980). Multiple opiate receptors: [3H]ethylketocyclazocine receptor binding and ketocyclazocine analgesia. Proc Natl Acad Sci USA 77: 3691-3694.

Pfeiffer A, Brantl V, Herz A, Emrich HM (1986). Psychotomimesis mediated by kappa opiate receptors. Science 233: 774-776.

Piazza PV, Deminiere JM, Le Moal M, Simon H (1989). Factors that predict individual vulnerability to amphetamine self-administration. Science 245: 1511-1513.

Porsolt RD, Bertin A, Jalfre M (1977). Behavioral despair in mice: a primary screening test for antidepressants. Arch Int Pharmacodyn Ther 229: 327-336.

Prut L, Belzung C (2003). The open field as a paradigm to measure the effects of drugs on anxiety-like behaviors: a review. Eur J Pharmacol 463: 3-33.

Robinson TE, Berridge KC (2000). The psychology and neurobiology of addiction: an incentive-sensitization view. Addiction 95(Suppl 2): S91-117.
Rogala B, Li Y, Li S, Chen X, Kirouac GJ (2012). Effects of a Postshock injection of the kappa opioid receptor antagonist norbinaltorphimine (norBNI) on fear and anxiety in rats. PloS one 7: e49669.

Roybal K, Theobold D, Graham A, DiNieri JA, Russo SJ, Krishnan $\mathrm{V}$ et al (2007). Mania-like behavior induced by disruption of CLOCK. Proc Natl Acad Sci USA 104: 6406-6411.

Shippenberg TS, Heidbreder C (1995). Sensitization to the conditioned rewarding effects of cocaine: pharmacological and temporal characteristics. J Pharmacol Exp Ther 273: 808-815.

Svingos AL, Chavkin C, Colago EE, Pickel VM (2001). Major coexpression of kappa-opioid receptors and the dopamine transporter in nucleus accumbens axonal profiles. Synapse 42: 185-192.

Svingos AL, Colago EE, Pickel VM (1999). Cellular sites for dynorphin activation of kappa-opioid receptors in the rat nucleus accumbens shell. J Neurosci 19: 1804-1813.

Tejeda HA, Shippenberg TS, Henriksson R (2012). The dynorphin/ kappa-opioid receptor system and its role in psychiatric disorders. Cell Mol Life Sci 69: 857-896.

Thompson AC, Zapata A, Justice JB Jr., Vaughan RA, Sharpe LG, Shippenberg TS (2000). Kappa-opioid receptor activation modifies dopamine uptake in the nucleus accumbens and opposes the effects of cocaine. J Neurosci 20: 9333-9340.

Tomasiewicz HC, Todtenkopf MS, Chartoff EH, Cohen BM, Carlezon WA Jr. (2008). The kappa-opioid agonist U69,593 blocks cocaine-induced enhancement of brain stimulation reward. Biol Psychiatry 64: 982-988.

Valjent E, Bertran-Gonzalez J, Aubier B, Greengard P, Herve D, Girault JA (2010). Mechanisms of locomotor sensitization to drugs of abuse in a two-injection protocol. Neuropsychopharmacology 35: 401-415.

Van't Veer A, Yano JM, Carroll FI, Cohen BM, Carlezon WA Jr. (2012). Corticotropin-releasing factor (crf)-induced disruption of attention in rats is blocked by the kappa-opioid receptor antagonist JDTic. Neuropsychopharmacology 37: 2809-2816.

Walker BM, Valdez GR, McLaughlin JP, Bakalkin G (2012). Targeting dynorphin/kappa opioid receptor systems to treat alcohol abuse and dependence. Alcohol 46: 359-370.

Wang YJ, Rasakham K, Huang P, Chudnovskaya D, Cowan A, Liu-Chen LY (2011). Sex difference in kappa-opioid receptor (KOPR)-mediated behaviors, brain region KOPR level and KOPR-mediated guanosine 5'-O-(3-[35S]thiotriphosphate) binding in the guinea pig. J Pharmacol Exp Ther 339: 438-450.

Wee S, Koob GF (2010). The role of the dynorphin-kappa opioid system in the reinforcing effects of drugs of abuse. Psychopharmacology 210: 121-135.

Wise RA, Bozarth MA (1987). A psychomotor stimulant theory of addiction. Psychol Rev 94: 469-492. 